\title{
Implantación de la Iglesia de la Asunción de Llíria (España). Origen y consecuencias
}

\author{
Embedding of the Church of the Asunción of Llíria (Spain). \\ Origin and Consequences
}

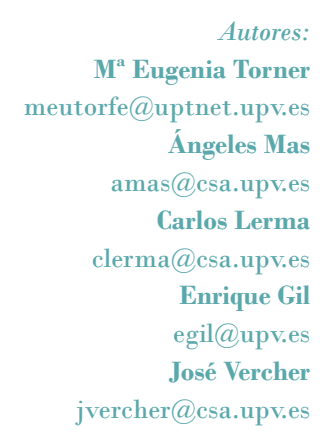

Universitat Politècnica de València

España

Recibido:12/Nov/2018 Aceptado: 12/Abr/2019

\section{Resumen}

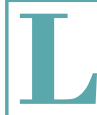

a peculiar implantación de la iglesia de la Asunción de Llíria (Valencia) despierta un gran interés debido a la magnitud de la obra de desmonte Esta elección supuso una ruptura radical con la morfología de la trama urbana existente, llegando incluso a deslavazar la composición de la ciudad y a arrollar parte de la muralla existente. La línea de investigación llevada a cabo unifica el estudio de las huellas históricas con las trazas que aún perduran. A este hecho se añade la dificultad de la falta de documentación, principalmente gráfica, que concierne a la iglesia. Una de las principales cuestiones que se abordan en este artículo consiste en qué supuso la elección de ese emplazamiento y qué consecuencias compositivas y paisajísticas tuvieron.

Palabras clave: composición urbana, iglesia, entorno patrimonial, estudio cartográfico, desarrollo urbano.

\section{Abstract:}

The peculiar embedding of the construction of the church of the Asunción in Llíria (Valencia, Spain) arouses great interest because of the extent of the land cleared out to build the temple. This election led to a radical rupture with the morphology of the existing urban area, to the point of disjointing the composition of the town and trampling part of the existing town wall. The research conducted unifies the study of historical footprints with that of the traces still remaining. The lack of documentation concerning the church, especially of graphic type, has made this task difficult. The election of the site, along with the compositional and landscape consequences of the works, is one of the main issues covered in this article.

Keywords: urban composition, church, heritage building surroundings, cartography study, urban development. 


\section{Introduction}

The Church of the Asunción of Llíria (1626-1627) is one of the most important Baroque temples (Petrickova \& Joja 2016; Bérchez, 1993; Domingo, 1996; Juan, 2006) among the architectural examples of this period in Spain, due to both its proportions and its cultural and artistic interest. Built during the seventeenth century, the church reflects clearly the Counter-Reformation laws, about which little is known, and little has been studied. Not only the building itself is an important architectural work, but also, due to its chosen location (Pace, 2014; Loseby, 2011) in the XVII century, it became a work of engineering worthy of study for its time (Torner, 2015).

There are few data on the construction of the building. The only thing we know is that, as the chroniclers of the time affirm, the traces of the building are entrusted to Father Pablo Albiniano de Rojas and were subsequently modified in 1628 (Marti, 1986). Of the master builders involved two are the names we have been able to know: Tomas Leonart Esteve and Martín de Orinda.

The building is located in the section of the Sangre hill (Figure 1), through a completely vertical section of the mountain, where it was necessary to carry out an enormous work of land clearing. The church is embedded partly within the mountain, as seen in both Figure 1 and Figure 2 .

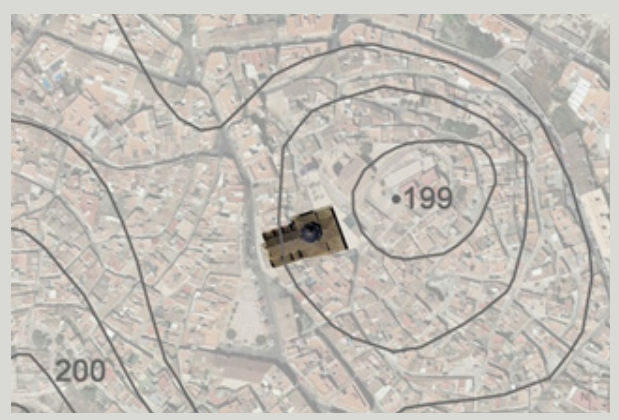

Figure 1: Aerial view of the church site with contour lines. Aerial photo of the National Cartographic Institute modified by the authors.

Source: Own.

This led to a dismantling of not only the urban structures of the moment, but the extent of land cleared out is such, that part of the Islamic wall (Fujiwara, 2016) was destroyed to build the Church of the Asunción.

Some doubts appear regarding the difficulty that supposed this morphological alteration and the choice of this peculiar site with the abruptly changes of the traces pre-existing until the moment. In spite of this, it was decided to establish the church in this place by creating a focus of attraction, as happens in other cases (Shoval \& Strom, 2014).

It is necessary to take into account that, in order to construct the church, they had to acquire more than 2,000 square meters of land in the new urban nucleus. This nucleus was located outside of what was considered then the centre of the town.

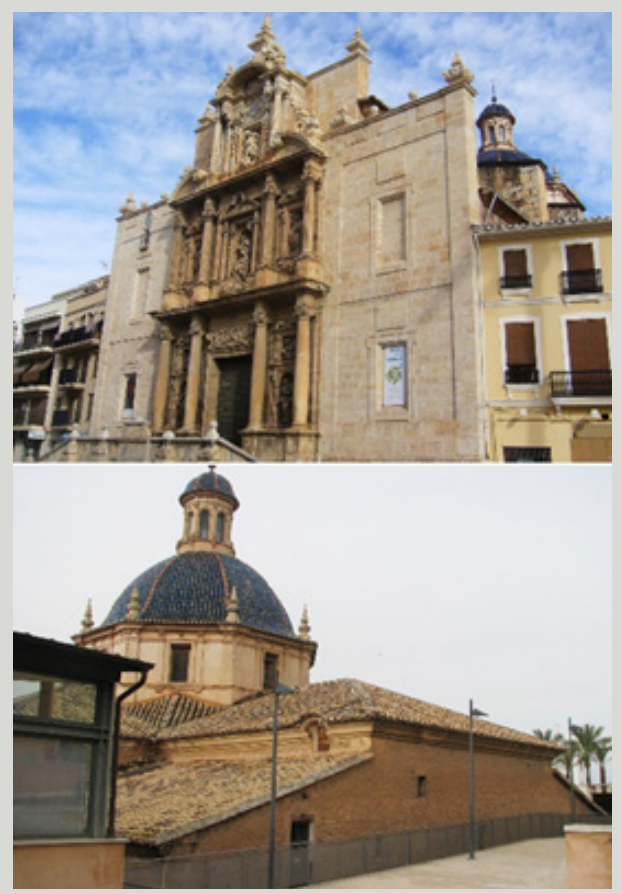

Figure 2: View of the church. 2-left.: View of the main facade of the church; 2-right.: View of the rear facade.

Source: Own.

This acquisition was of great relevance, given the monumentality of the construction and the size of the villa (Domingo, 1996). This represented an architectural challenge for the moment as seen in the Figure 3.

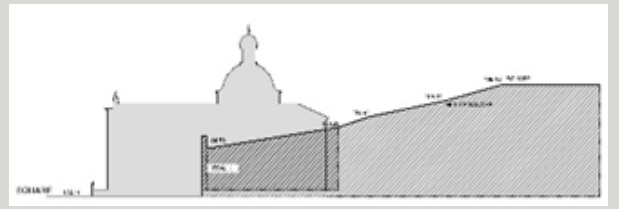

Figure 3: Section of church grounds.

Source: Own. 
Multiple questions arise when trying to understand the reason for this implementation. We consider urban heritage as a social, cultural and economic capital that generates multiple values. The urban traces become, therefore, the History book of the city, by implicitly suggesting the events and allowing us to recognize them at each step.

The essence of any city is marked by the multiple modifications and transformations performed to its structure, which invariably leaves a chink of the unbroken original plot. Its form, its concept, its geometry and its composition give us clues to how the traces have been fitting and conforming themselves into the cities (Chias \& Abad, 2008).

In order to carry out the study, it was essential to know the existing up to date graphic documentation (Inostroza, 2015; Cianci, 2016; Ortiz, 2016). Unfortunately, when we set out to gather all the graphic information of the urban evolution taking place before and after the construction of the church of the Asunción, in order to understand the chosen location and how the implantation of the city influenced the urban traces, we found that this documentation was mostly burned during the Spanish Civil War (1936-39) and that the rest disappeared as a result of events(Garcia, 2016; Song, Dai \& Li, 2017; Marques, et al., 2017).

Taking this fact into account and considering that we do not only consider buildings as heritage, but also historical urban groups, which constitute an essential testimony in our history, we saw the need to try to recreate a hypothesis of urban evolution with the documentation found.

\section{Methodology}

The urban traces are characterized because they are difficult to erase, and they form the backbone of any urban structure, giving it a historical geometry that tells the passage of history and the characteristics of their time. These involve stories about the place that help to understand the historical context of the moment and can relate the past to the present.

The need to understand this rupture in the morphological structure of the city and its consequences mark the turning point in the line of research of this work.

In order to obtain the development of the traces, with the lack of graphic documentation that could shed a little light on this research, we saw the need to study the urban evolution of the city of Llíria. With this goal in mind, we had to go back to the first vestiges found of the first settlers - due to the lack of urbanistic documentationand trace a chronology that would show the stages leading up to the construction of the church. A study of how the city of Llíria had been forming until the 17th century, with the objective of obtaining a hypothesis of the essential traces that connect the existing city with its evolution until that moment.

It must be taken into account that the existing graphic documentation is the Land-use planning of 1956, and that there are only a few specific graphical references by some chroniclers of the city, due to the destruction of this documentation as already mentioned above.

The method used has been the analysis of the existing urban morphology along with the collected historical documentation, and the development of a hypothesis of the urban traces across stages traces (Echeverria, Celis \& Da Casa, 2015). All this has allowed us to obtain graphic documentation of the city, locating in it the very important vestiges found up to know that exist in Llíria.

In addition to it, in order to carry out the appropriate research, we have also considered the existing urban treaties at the time, in order to complement our hypothesis with similar cases near the studied area.

\subsection{The traces inherited up to the 15th century}

The geographical area of the city of Llíria is characterized by three distinct zones. The first zone, the most northern, is occupied by a chain of hills that physically delimit the valley of the city that would be the second zone. The third area would be where the current population and the area of the orchard are located. In the first zone, in the chain of hills is where the city with the name of Edeta has its origins in the 6th century B.C.E. An extensive network of watchtowers that became an opulent city of 10 ha. But due to its political and economic characteristics and its strategic position, Edeta played an important role in the Roman civil wars, resulting in the destruction of the Sertorio settlement in 76 (Nussdorfer, 2015) and occupation from Rome (Konvitz, 2013; Gonzalez, Rodriguez \& Belmonte, 2014). The Roman alliance changes the settlement model (Taylos, 2013) from high places of easy defense characteristic of the Ibero model to the model of settlement in plains or smooth slopes. Its inhabitants moved to the plain, and the sites for defensive purposes were replaced by sites with the purpose of taking advantage of water resources and mastering the main roads of communication.

Such is the importance of the city in Roman times, that in Llíria there are some of the most important Roman works in Spain, such as the Doce Trabajos de Hércules mosaic (which is nowadays in the Museo Arqueológico Nacional in Madrid), the Oracular Sanctuary, and one of the most important samples of funerary architecture in Spain, such as the mausoleums of the 1st century.

The location of these and the study of other less important vestiges that have been found in the city mark not only the nucleus of settlement but also the traces through the main axes, which were created to foment commerce. These axes connect with more important 
cities, like Valencia, and begin to define the urban traces of the city as shown in Figure 4.

But the present settlement would come with the Islamic period (Martí, 1987) and its preferred models of settlement, which again favored places of easy defense, situated in the present hill of the Sangre, Figure 5, and the current nucleus of the old town. Following the outlines of Islamic cities of that time, there should be two clearly differentiated parts: the Alcazaba and the Medina. The Medina, completely walled, protected the citizens.

It had different public facilities: the mosque, the souk and the baths, which were the main meeting places of the community. The mosque occupied the central point of the city, oriented to the southeast, which conditioned the layout of the new city. It was the center of religious life, but also a place of cultural, educational and judicia activities, whose remains are integrated within the Church of the Blood (la Sangre in Spanish), located in the center of the city. It was also the converging point of the streets and was adjacent to one of several cisterns from which, by gravity, welled the networks of water pipes. The hammam, Islamic baths (Valencia, 2010; Garcia, 2016) of the 17th century, were located outside the wall, next to the main irrigation ditch from which it was supplied (Llibrer, 2003).

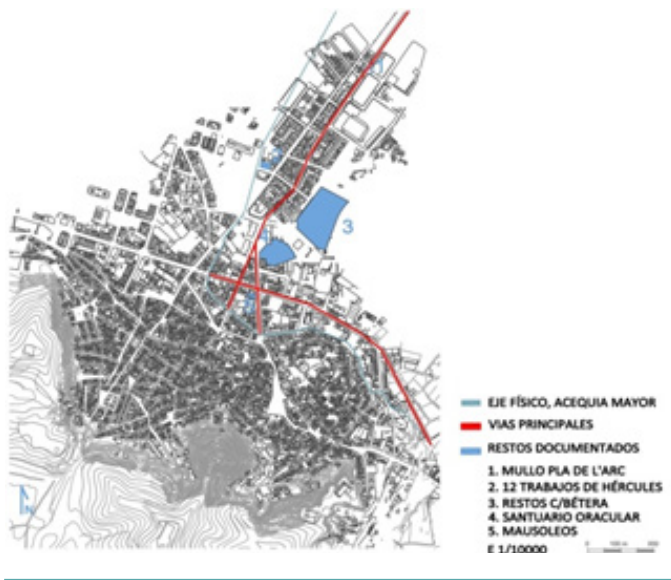

Figure 4: Location map of the remains found in the city of Llíria.

Source: Own.

The urban structure was made up of streets that were adapted to the level curves of the terrain and arranged radially as shown in Figure $5 b$, with the main streets leading to the four gates of the walls. The four main streets cross four squares arranged concentrically to the central square.

The city was organized in neighborhoods, which had each basic services, and which formed some narrow streets with large slopes and other streets with no exit. These were called Muslim atzucats, of which there are still remains where they can be appreciated nowadays.

In the year 1239 the king Jaime I conquered (Cuberes \& Gonzalez-Val, 2017; Georgopolou, 1994) the city and in
1253 granted the Carta Puebla (village charter) (Marti, $L, 1987$ ) that confirmed the city of Llíria as a royal village. The village was repopulated by Christians of Catalan and Aragonese origin, given its location in one of the main axes of communication with Valencia and its strategic location

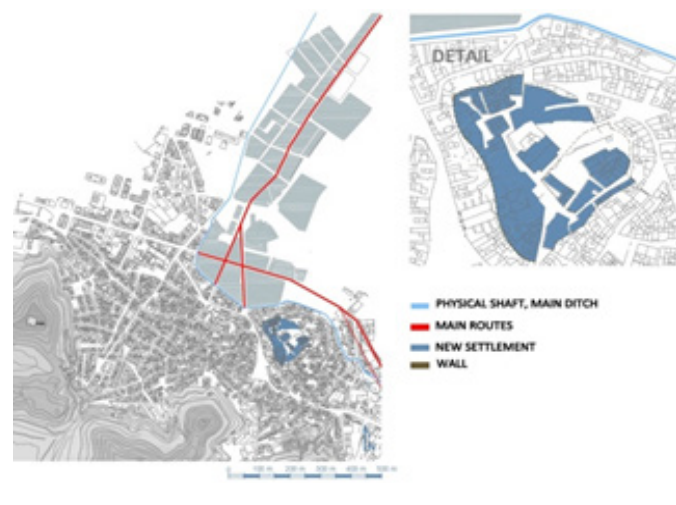

Figure 5: Situation of the settlement of the hill of the Sangre, Old Villa, with respect to the present city. 5-left. General View; 5-right.: Settlement detail.

Source: Own.

The small number of repopulations was probably what led the new settlers to reuse existing Islamic spaces by converting the former fortress into their castle, orchards and houses into their homes and the mosque into a church, all within the existing village walls (Llibrer, 2003).

According to the traces back from the Christian period, the atzucats were opened to improve communication among the streets and the city is organized around a series of military and defense structures or buildings both civil and religious, some of which are present in both the Muslim and Christian times.

The military structures of defense and control were fortifications that delimited space and in turn represented power and social control, such as the fortress, the castle and the walls (Doratli, Hoskara, Vehbi \& Beser, 2007).

Religious buildings, such as the mosque, the church, the synagogue, and the hospital, were both worship spaces and places where they could socialize and make decisions regarding the community.

Of these buildings, the church of Santa Maria is still preserved, which is well-known nowadays as the 13th century church of the Sangre that was built on the mosque site. This temple is an excellent Valencian architecture example of churches built during the conquest period, with constructive elements of transition from Romanesque to Gothic.

The Medieval Hospital is another preserved building since its construction at the end of the 13th century which since the 14th century became known as the church of the Good Shepherd (Iglesia del Buen Pastor). 
Some village houses from this period have maintained their characteristic portals with semicircular arches and wide interior rooms with diaphragm arches. The most singular building of this type is the village baker's, which dates from the 15 th century.

Other remarkable building is Ca la Vila Vella, also from the 15th century, and which has recently been rehabilitated. This was formerly the chamber of the city council, in other words, the former town hall. There are some arches in the delegation of the rehabilitation office building that because of their structure, they might have been part, along with Ca la Vila, of an architectural ensemble. This became one of the most important elements in the urban delimitation, and therefore, in the evolution of the city.

The town experienced a growth in population due to several factors: one was that the last orchard lands of the interior of the country attracted new inhabitants and others were due to the natural growth of the town (Chias \& Abad, 2016; Ersoy, 2015; Martí, 1987; Boerenfijin, 2016). These reasons motivated the first expansion of the wall carried out in the last third of the 13th century, as shown in Figure 6.

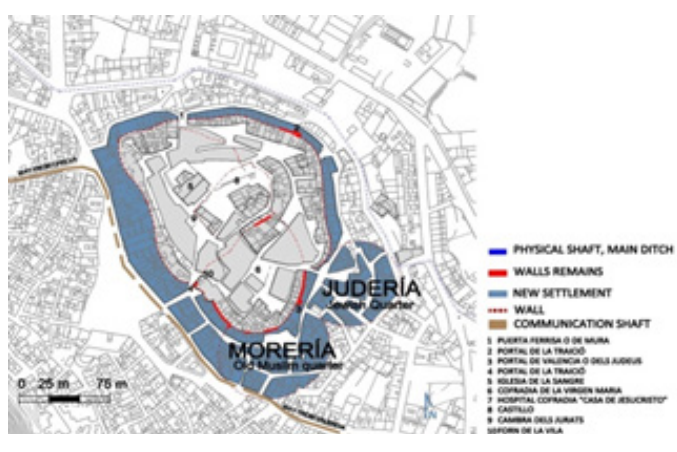

Figure 6: Christian Llíria with extension of outside the walls.

Source: Own.

During the first half of the 14th century, decrees were issued to raise funds for the repair and rebuilding of the city walls. This expansion would be carried out on the southeastern side, leaving some material traces, such as the Portal de la Traició (Treason Gate), which became the best sample of the Mudejar architecture of the period.

The second extension of the walls is determined by the steady population growth of the town, as well as the plague waves, which continued until the 14th century. This expansion counted with the existing physical limits, such as the irrigation ditch, the baths, the orchard and the mills, which led to its implementation on the north side, following the established morphology, as shown by some of the vestiges found.

There were several factors that conditioned growth outside the walls, but the most important ones were the physical boundaries existing both north and south. On the south side there were a series of hills that formed a physical barrier thus limiting the expansion of the village on this side.
On the other hand, the north side is where the irrigation ditch is located, forming a physical barrier of expansion, since this is the most essential element for the local economy, being the source of water supply for all the orchards of the valley.

Given these conditions, three neighborhoods grew outside the walls of the town, of which we have record according to the research of local historians.

The first two, the Morería (Muslim quarter) and the Judería (Jewish quarter), were located to the east of the walls and were situated between the main ditch and the road to Valencia. They were close to the baths and several villages populated by converted Muslims such as Benisanó and Benaguasil, as shown in Figure 6. The other district, also called Morería, was located between the hillsides that delimit the physical barriers of the city.

For centuries, cultural barriers have prevented the growth of the village in those directions, given the cultural bias of the villagers towards Jewish and Muslim neighborhoods.

\subsection{The basal traces of the city in the 17th century}

The layout development that took place during the 15th century was marked by the population's demographic and economic growth, to the point that this expansion could not be contained within the walls.

During the sixteenth century (Pingarrón, 1995) and almost all of the seventeenth century, the city reached its period of greatest economic and demographic growth. Unlike what happened in most of other places, the expulsion of the Moriscos (Muslims converted to Christianity) in 1609 did not affect the town, because the majority of the population was made up of Old Christians (Chias \& Abad, 2016; Ersoy, 2015; Martí, 1987; Boerenfijin, 2016).

The importance of the communications with Valencia and the Serranía conditioned the growth of the town, which was structured along two major axes: the roads to Valencia and Chelva (Camí de Valencia and Camí de Chelva, respectively). In addition to these, we must consider the axis of the Pla de l'Arc, which has existed since the Roman age. The city center then moves to the main square (Plaza Mayor).

Due to the urban development that took place around this communications hub and the new main square, other neighborhoods began to develop right outside the walls.

The most important period of the 16th century brought along the construction of L 'Almodí (1595), which was intended to be a storage space, a prison and the chamber of the city council, therefore becoming the most important building of the city.

The site chosen for the building was the most strategic block of the arcaded Plaza Mayor, which was located on a plateau between hills that gave the square its triangular 
shape. This intended location would allow the building's main facade to loom over the main communication route as seen in Figure 7.

With the completion of the Almodí at the beginning of the 17th century, it was agreed that a new church would be built outside the walled perimeter, which would be located in the new town center, and whose dimensions would match the population at that moment.

This location was set up a few meters away from the Almodí building, specifically on the southern slope of the mound of Sangre, which could link with the aforementioned physical barrier of hills.

By then, the center of the city had shifted to the presentday Plaza Mayor, and the Church of Sangre, in addition to its small dimensions, was located on the top of the hill. Conversely, the location chosen for the new temple had the appropriate dimensions and accessibility for the new era.

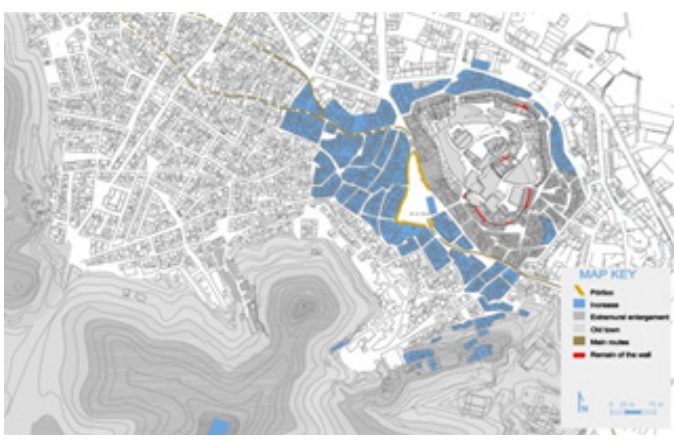

Figure 7: Map of the city of Llíria in the 16th century. Source: Own.

This location followed the baroque urbanism guidelines (Maiques, 2003) of that time, which took the people as reference and sought for converging places that would concentrate and integrate several buildings into a good communications network. The square would be used as an anteroom, by seeking vast spaces for the different buildings.

This site complied with Fray Isidoro Aliaga's guidelines, who was one of the highest exponents of Valencian Baroque architecture. He advised that there should be a space in front of the church to be built, a square where the size would match the grandeur of the temple and the town, without becoming excessive.

For the location of the church and opposed to the custom of building churches on mounds, Aliaga recommended building on flat areas, although this was more difficult to accomplish in towns than in cities, because of their orography. If the building must be built on a hillside or the slope of a mound, he recommended to plan for water drainage, in order to avoid any possible damages in the construction.
Aliaga also pointed out the importance the church being isolated from other buildings, that is, that the temple be exempt from adjoining buildings. Although there are adjacent buildings today, it is believed that the church could have been built apart from any building, based on the design of the temple facades.

With the purpose of creating the main nucleus on a flat area, and due to the population increase and the town growth that it entailed towards the northwest by the Camino Real (Royal road), the plaza Mayor was enlarged in order to integrate the church and to host more representative buildings, and hence conform to Aliaga's recommendations (Torner, Mas, Lerma, Gil \& Gil, 2015).

At the end of its construction, it was ordered that all the arcades of the square be demolished, conforming the urban plot that has been maintained to this date. The second half of the 17th century represented, for the present-day city of Llíria, a new stage of demographic and urban growth as shown in Figure 8.

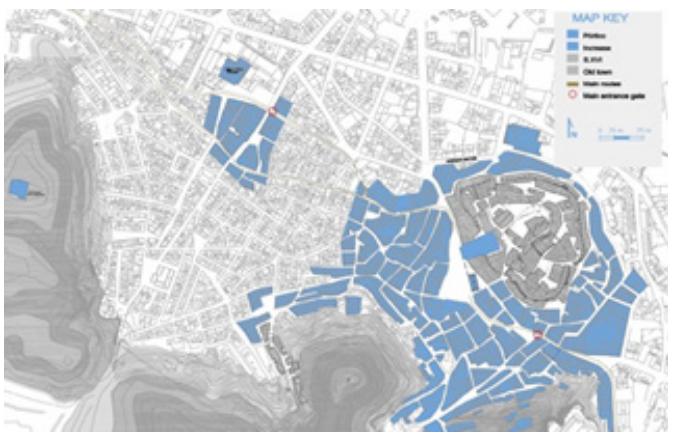

Figure 8: Plan of the XVII century of the city. Source: Own

Next, Figure 9 shows how the traces have developed in later centuries departing from the traces of the 17th century.

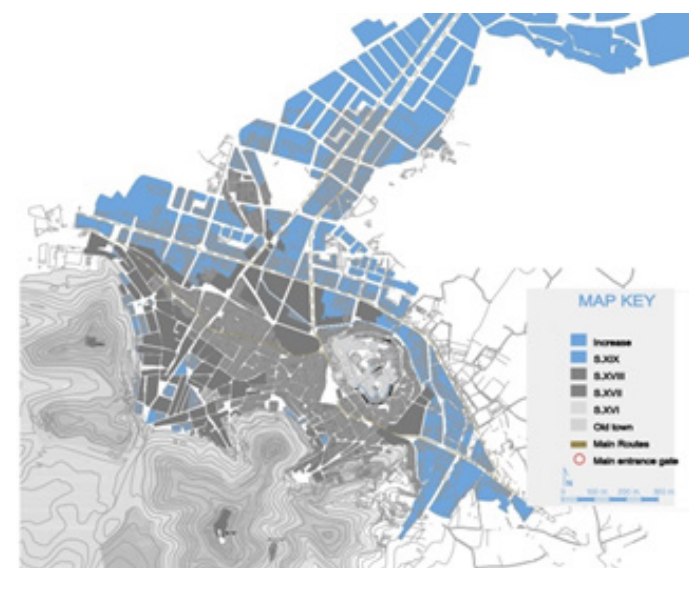

Figure 9: Evolution of the layout of the city. Source: Own 
The urban evolution of the town was a continuous expansion, where different historical facts gradually marked the current traces of the city, preserving previous traces and the area of the orchards, which were a source of income for the city.

\section{Results}

In order to establish a chronological evolution for the traces in the city of Llíria it has been essential to study written documentation and to conduct field work. The location of the existing archaeological milestones or elements, supported by the research of their history, have marked the basis of this investigation. This has allowed us not only to produce new graphic documentation, but also the contextualization of the city according to its traces, which is also a source of great interest for the city.

The in-depth knowledge of the traces, the streets, the communication axes, the original layout of the streets persisting in time, etc., allow us to get immersed in the past by studying the material tracks.

The importance of the origin of the urban plot in the reconstruction of historical moments that mark the life of a city possesses a historical as well as an urban value, which adds an artistic value: the conception of space considering durability across times.

In order to understand this implementation, it is necessary to take into account that, in Spain, the Baroque style included working over inherited urban plans and the conception of new open spaces, giving maximum prominence to the major plazas and - within these - the religious architecture, that is, the churches.

The search by the Valencian urbanism of the Baroque for a congregation point encompassing not just all of the most remarkable buildings in the city, but also the transit from the most important communication networks, led the city of Llíria to force an implantation in the church of the Asunción.

With these specific guidelines, the church was located in the new Plaza Mayor, in front of a major communications hub that went across the city, such as the road to Valencia, and next to the most characteristic building of the time. A temple of great dimensions and great beauty, whose facade was even slightly inclined in order to support the visuals of L'Almodí building, thus in turn complying with the specific premises of the baroque.

But even though a perfect balance seems to have been achieved when looking from the Plaza Mayor, terrible consequences arise in the rear side of the square.

The location of the church here had multiple consequences, among them the breaking of the traces of the existing Islamic plot, cutting some original streets, as well as a section of the wall, and the essence of the old village. This meant the rupture with a landmark such as the wall, which surrounded the old core and that remained embedded within the church.

As it can be seen in Figure 10, the back part of the church is very close to the early church, the Church of the Sangre, thus covering any panoramic view of it, destroying any compositional scheme, and producing a break in history.

The consequences of this decision led to the location of the back of the church embedded into the hill which has led to a disastrous situation as shown in Figure10.

As can be seen in Figure 10-left, with the passage of time, other houses have been attached to the lateral facades of the church, not in their entire length, but approximately half of it, leaving a minimal circulation space behind the church. In Figure 10-right, the shoring of the containment work in the vertical section of the hill can be observed with an ominous intervention as a consequence of the adaptation work carried out during the second half of the 20th century, which affected the neighboring street.

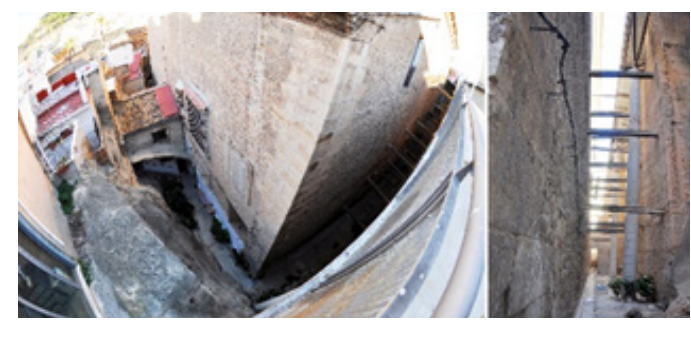

Figure 10: Exterior views of church. 10-left: General view of the back church; 10-right.: Detai of the containment of the ground clearing wall. Source: Own.

\section{Conclusions}

When we decided to study the church of the Asunción in Llíria and found ourselves with its peculiar implantation, we saw the need to understand the reason for choosing this location. Its singularity and the difficulty of the land clearing work, along with what this meant for the traces of the city, has been the basis of our investigation questions.

To all these questions was added the challenge of the lack of documentation, mainly graphic, that could help us understand this extreme choice for the temple location.

With this lack of information, we have had to elaborate a detailed study based on the historical context, the archaeological remains found, as well as sketches and sketches and various photographs to be able to locate and to draw the different maps shown in this study.

Making these maps, showing the evolution of the city from the first settlers until the 20th century, has been essential in order to observe the reasons behind the 
impressive implantation of the church in the 17 th century and its subsequent influence on the urban plot of Llíria.

The volumetric dimensions of the Church of the Asunción suggested a contradiction in the coherence of development and the urban evolution of the moment. The unevenness that occurred with the insertion of the church into the hill was not resolved and, as of today, has not yet been resolved.

But the result, curiously, has been this great work that has become one of the most representative examples of the Valencian Baroque. The strength of its interior and its main facade make us forget the rupture that its implantation meant for the landscape.

This building, the church of the Asunción of Llíria, represents another example of incoherent processes that have occurred in the history of architecture, but which in turn has originated the result of an exemplary building.

\section{References}

- Bérchez, J. (1993). Arquitectura barroca valenciana Valencia, España: Bancaja.

- Boerefijin, W. (2016). About the Ideal Layout of the City Street in the Twelf to Sixteenth Centuries: The Myth of the Renaissance in Town Building. Journal of Urban History 42 (5), 938-952. Doi: 10.1177/0096144214566983.

- Chias, P. \& Abad, T. (2008). Visualising ancient maps as cultural heritage: A relational database of the Spanish ancient cartography. 12th International Conference Information Visualisation. England.

- Chias, P. \& Abad, T. (2016). Spanish Landscapes in the Middle Ages: Reconstructing Territorial Memory from Early Documents and Cartography -A GIS-Based Methodology, Cartographica: The International Journal for Geographic Information and Geovisualization, 51 (4), 208-220. Doi: 10.3138/cart.51.4.3284.

- Cianci, M.G. (2016). Management, reconstruction and communication of complex urban systems. The Suburra district in Rome. Disegnare Idee Immagini, 52, 80-90.

- Cuberes, D. \& Gonzalez-Val, R. (2017). The effect of the Spanish Reconquest on Iberian cities. The Annals of Regional Science, 58, 375-416. Doi: 10.1007/s00168 017-0810-0.

- Domingo, A. (1996). La crisis Del Siglo XVII: Ia población, la economía, la sociedad. Madrid, España: Espasa Calpe.

- Doratli, N., Hoskara, S., Vehbi \& Beser O. (2007). Revitalizing a declining historic urban quarter-The walled city of Famagusta north Cyprus. Journal of architectural and planning research, 24 (1), 65-88.

- Echeverria Valiente, E., Celis D’Amico, F. \& Da Casa Martin F. (2015). Drawing as a research tool: Reconstruction of the trip time of the urban image of Alcalá de Henares. EGA Expresión Gráfica Arquitectónica, 25, 180-191. Doi: 10.4995/ega.2015.3678.

- Ersoy, A. (2015). Cosmopolitan Attachment Pluralism and Civic Identity in Late Ottoman Cities. Journal of Urban History, 41 (3), 521-525.

- Fujiwara, S. (2016). The walled cities, Art forum International, 104-144.

- Garcia, C.C. (2016). The historical cartography as a method of morphological study of the traditiona landscape of Campanar. EGA Expresión Gráfica Arquitectónica, 21 (27), 254-261. Doi: 10.4995/ ega.2016.4745.

- Georgopolou, M. (1994). Patterns in urban designThe ideology of medieval cities. American Journal of Archaeology, 98 (2), 309-309. 
- Gonzalez, A., Rodriguez, A. \& Belmonte, J.A. (2014). The orientation of Roman towns in Hispanian: preliminary results. Mediterranean archaeology \& Archaeometry, 14 (3), 107-119.

- Inostroza, S. (2015). La herencia de las trazas en la ciudad existente: Geometría y continuidad en la morfogénesis del proyecto urbano contemporáneo. VII Seminario Internacional de Investigación en Urbanismo, Barcelona-Montevideo. Barcelona, España: Departament d'Urbanisme i Ordenació Del Territori. Universitat Politècnica de Catalunya.

- Juan Vidal, F. (2006). Valor barroco en la arquitectura valenciana. Valencia, España: TC Cuadernos. General de Ediciones de Arquitectura.

- Konvitz, J. (2013). Contemporary urban history: what the study of port cities Implies for evidence, methodology, and conceptualization. Journal of Urban History, 39 (4), 801-806. Doi: 10.1177/0096144212470248.

Llibrer, J.A. (2003). El finestralgòtic: l'esglèsiai el poble de Llíria als segles medievals. Llíria, España: Ajuntament de Llíria.

- Loseby, S.T. (2011). Reflections on urban space: streets through time. Reti Medieval Rivista, 3.

- Maiques, J.V.C. (2003). Science, politics and image in Valencia: a review or urban discourse in the Spanish City. Cities 20 (6): 413-419. Doi: 10.1016/j.cities.2003.08.007.

- Marques, L., Tenedorio, J.A., Burns, M., Romao, T., Birra, F., Marques, J., \& Pires, A. (2017). Cultural Heritage 3D modelling and visualization within an augmented reality environment, based on geographic information technologies and mobile platforms. Ace-Architecture City And Environment, 11 (33), 117-136. Doi: 10.5821/ ace.11.33.4686.

- Marti, L. (1987). Los Trinitarios Calzados en la villa de Llíria o a la historia Del "Remey" (1586-1987). Llíria, España: Parroquia Nuestra Señora de la Asunción.

- Martí, L. (1986). Historia de la muy ilustre ciudad de Liria. Llíria, España: Sociedad Cultural Llíria XXI.

- Nussdorfer, L. (2015). Rome: Continuing Encounters between Past and Present. Burlington, USA: Ashgate Publishing Co.

- Ortiz de Villajos Carrera, J.C. (2016). Urban derives and literary cartographies: heritage portraits of the present. Proyecto, progreso, arquitectura, 14, 54-67. Doi: 10.12795/ppa.2016.i14.04.

- Pace, S. (2014). History of urbanism in Spain, vol. 2, Centuries XVI, XVII and XVIII. Planning Perspectives, 29 (1). Doi: 10.1080/02665433.2013.860824.

- Petrickova, M. \& Joja, M. (2016). Interpretation of traditional structural principles in contemporary architecture. 8TH Architektura V Perspektiv. Ostrava, Czech Republic: Ostrava Technical University.

- Pingarrón Seco, F. (1995). Las advertencias para los edificios y fábricas de los templos del sínodo del arzobispo de Valencia Isidoro Aliaga en 1631: Estudio y transcripción. Valencia, España: Asociación Cultural La Seu.

- Shoval, N. \& Strom, E. (2014). Inscribing universal values into the urban landscape: New York, Jerusalem, and Winnipeg as case studies. Urban Geography, 30 (2), 143-161.

- Song, F., Dai, Y. \& Li, N.T. (2017). Reflections on the gap between academic research in urban morphology and heritage conservation. Urban Morphology, 21 (1), 87-89.

- Taylos, J. (2013). Roman urbanism: a view from the countryside. Oxford Journal of archaeology, 32 (4), 413432. Doi: 10.1111/ojoa.12022.

- Torner, M.E. (2015). Sistemas de análisis mediante la aplicación de nuevas herramientas al estudio morfológico constructivo de la iglesia de Nuestra Señora de la Asunción (Tesis doctoral). Universidad Cardenal HerreraCEU, Valencia, España.

- Torner, M.E., Mas, A., Lerma, C. \& Gil, E. (2015). Metodología para el estudio de las trazas y las relaciones intrínsecas en la Iglesia de la Asunción de Llíria. Informes de la construcción, 67 (538), e070. Doi: 10.3989/ic. 13.118.

- Valencia, A. (2010). Islam, The City, The City in Islam. Journal of Urban History, 36 (6), 906-909.Doi: 10.1177/0096144210374453. 